\title{
Pattern and predictability of potential wind assistance for waders and geese migrating from West Africa and the Wadden Sea to Siberia
}

\author{
THEUNIS PIERSMA \& SJON VAN DE SANT
}

\begin{abstract}
We have analysed published wind data from the period 1979 1991 to evaluate to what extent migrating waders and geese might benefit from tailwind assistance when flying at altitudes ranging from ground level up to $5.5 \mathrm{~km}$ from West Africa (Banc d'Arguin, Mauritania) to the Wadden Sea (Netherlands, Germany and Denmark) in late April and early May, and from the Wadden Sea to Taymyr Peninsula (central Siberia) in late May and early June. Between West Africa and the Wadden Sea it is usually advantageous to fly high, with an average tailwind of $15 \mathrm{~km} / \mathrm{h}$ (mean of yearly averages) for those birds flying along the optimal height track. There were large differences between years though, with $36 \mathrm{~km} / \mathrm{h}$ tailwind (1983) and $2 \mathrm{~km} / \mathrm{h}$ headwind (1991) as extreme values. The best altitudes for migration were higher along the northwest African coast than over Europe. There was no evidence for consistent seasonal changes in wind favourability, but "bad"

years were consistently bad over the whole season. Between the Wadden Sea and the Taymyr Peninsula wind conditions were better still than for the Banc d'Arguin-to-Wadden Sea journey (long term average for flights along optimal height track is $21 \mathrm{~km} / \mathrm{h}$ tailwind), with the favourable winds found at intermediate altitudes $(1.5-3 \mathrm{~km})$. The wind conditions were less variable between years along the Wadden Sea-Taymyr route. We discuss both the limitations of the current analyses and the scope for future work.

T. Piersma, Netherlands Institute for Sea Research (NIOZ), P.O. Box 59, 1790 AB Den Burg, Texel, The Netherlands, and Zoological Laboratory, University of Groningen, P.O. Box 14, 9750 AA Haren, The Netherlands.

S. van de Sant, Netherlands Institute for Sea Reserch (NIOZ), P.O. Box 59, 1790 AB Den Burg, Texel. The Netherlands.
\end{abstract}

\section{Introduction}

Migrating birds fly through a moving medium: the air. Air often moves at about the same speed relative to the ground as birds do relative to the air. Therefore migrants should make use of air currents flowing in seasonally appropriate directions (e.g. Richardson 1978, 1990a,b, Alerstam 1979a,b, 1990). Correlations between wind and migration patterns of waders and other birds have been indicated by several authors (e.g. Thomas 1970, Richardson 1979, Stoddard et al. 1983, Alerstam et al. 1986, Gauthreaux 1991). High arctic breeding Brent Geese Branta bernicla have been shown to return to the Dutch wintering grounds without young in years when they encounter unfavourable wind conditions during the northward flight (Ebbinge 1989). Migrating fish move through another moving medium, water, and face a similar problem (Weihs 1978). Indeed, fish too have been shown to make good use of favourable water currents (Metcalfe et al. 1990).

Recently, Piersma \& Jukema (1990) argued that Bartailed Godwits Limosa lapponica are unable to balance their early spring travel-energy budget if they fail to make use of favourable winds along the flight route, in this case from the Banc d'Arguin in Mauritania to the Dutch WaddenSea.Piersma et al. (1991) compared the body masses at departure from the last stopover site with the distances flown to the breeding grounds for two subspecies of Knots, Calidriscanutus canutus and C. c. islandica. This comparison suggested that Knots of the canutus subspecies, which migrates parallel to the dominant wind circulation patterns over the Eurasian continent between West Africa and Siberia, could routinely reap the benefits of favourable wind patterns. 


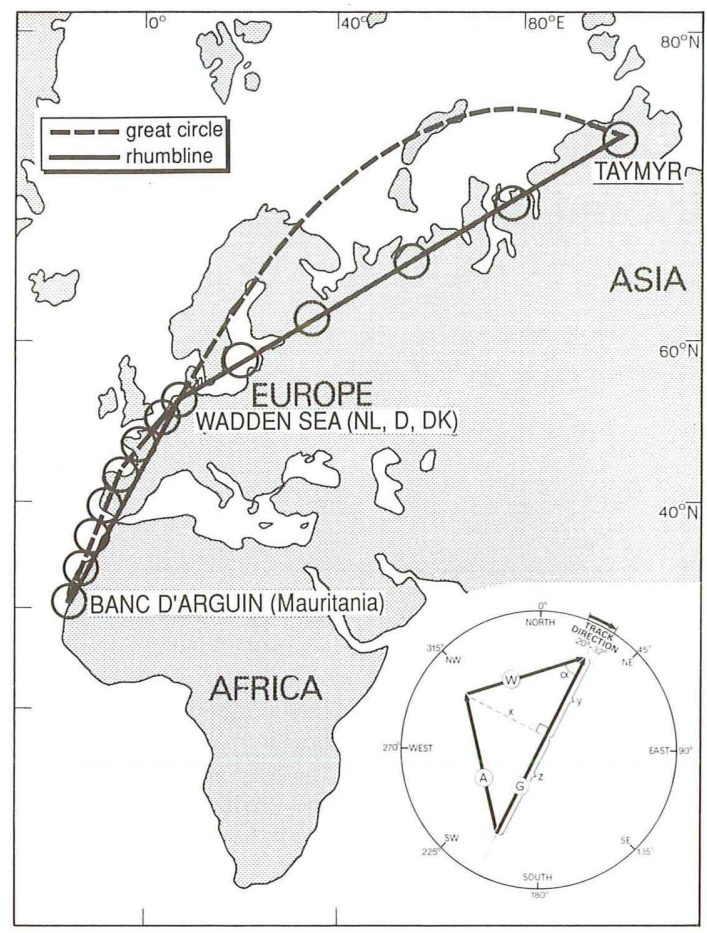

Fig. 1. The probable wader migration routes in spring between the Banc d'Arguin in Mauritania and the Taymyr Peninsula in Siberia. Both the rhumbline routes (constant compass heading) and the great circle routes (shortest distance over the globe) are shown (adapted from Alerstam 1981). Open circles show the approximate 'read out-locations' for the wind analyses. The inset gives the scheme (from Piersma \& Jukema 1990) that outlines how to calculate the wind effect $\delta W(=G-A)$ for birds flying in a fixed track direction, and with a constant airspeed, in a case where the wind blows from SSW. The three vectors $A$ (bird's airspeed and direction), $W$ (wind speed and direction) and $\mathrm{G}$ (groundspeed and track direction) are indicated by the encircled letters.

Troliga flygrutter för vadare på vårflyttning mellan Banc d'Arguin i Mauritanien och Taymyrhalvön i Sibirien. Två flygvägar är markerade: storcirkelrutten ("great circle", kortast möjliga avstånd) och "rhumbline", den rutt där fåglarna håller konstant kompassriktning (efter Alerstam 1981). Öppna cirklar visar lokaler där vinddata utlästs. Den lilla figuren visar hur den resulterande vindeffekten $\delta \mathrm{W}$ (= G-A) räknats ut för en fågel som flyger längs en förutbestämd rutt, med konstant hastighet gentemot lufthavet, i det här fallet med vinden från sydväst (från Piersma \& Jukema 1990). De tre vektorerna A (fågelns flygriktning och hastighet gentemot lufthavet), W (vindens riktning och hastighet) och $\mathrm{G}$ (fägelns flygriktning samt flyghastighet gentemot marken) är markerade med cirklar runt respektive bokstav.
They can therefore migrate relatively cheaply in terms of energy cost, a suggestion independently put forward by Gudmundsson et al. (1991).

Wind is but one of the meteorological variables affecting the life of birds (Elkins 1983). Air and soil temperatures, humidity, rain and snow, all affect birds at different times and in different ways. In a world with an apparently rapidly changing climate it becomes increasingly important to get to grips with these parameters so as to improve our understanding of their meaning for the well-being of migrant bird populations (see Boyd 1991 for some thoughtful comments). Most of the biologically relevant meteorological variables are already being measured routinely at many locations. Although they are rarely available in a form which can be readily used by ornithologists, the data sets are there to exploit. Understanding the biological implications of these meteorological variables (e.g. Boyd 1992) may become increasingly important.

This contribution is an attempt to use weather data for an ornithological purpose. We aim to document the wind vectors at different (flight) altitudes experienced by waders and geese migrating in spring from West Africa and/or the Wadden Sea (in The Netherlands, Germany and Denmark) to their central Siberian breeding grounds. More specifically, we compare the potential wind assistance during the first (Africa Wadden Sea) and second (Wadden Sea - Siberia) leg of an afro-arctic journey, and also look at seasonal and yearly variability in the occurrence of favourable winds along this flight route.

\section{Methods}

\section{Routes}

There is little direct evidence as to the exact routes that waders take during the flight from West Africa to Siberia in spring (Fig. 1). For Knots, visual as well as radar observations have indicated the flight routes within Europe: a direct overland flight from the Atlantic coast of France to the Wadden Sea (Dick et al. 1987), and then a flight from the Wadden Sea to the east over south Sweden and through the Gulf of Finland (Dick et al. 1987, Blomqvist \& Lindström 1992). Brent Geese are also known to migrate through the Gulf of Finland (J. Koistinen \& A. Harjo pers. comm. to W.J.A. Dick; see Dick et al. 1987). This implies the use of a rhumbline route (along a constant compass course) from the Wadden Sea to Taymyr Peninsula in central Siberia (Alerstam 1990; direction 59 ${ }^{\circ}$ ), and we base our wind analysis on this route.

Waders departing from the Banc d'Arguin, Mauritania, in spring oriented in a more westerly direction than the great circle route to the Wadden Sea (Piersma et al. 1990a). Since the rhumbline direction to the Wadden Sea is more eastward, and because the 
differences between the rhumbline and the great circle routes are small anyway during this leg of the journey (Fig. 1), we chose to base our wind analysis for the flight from the Banc d'Arguin to the Wadden Sea on the great circle route. This implies that the migrants have to adjust track direction from $22^{\circ}$ at departure from the Banc d'Arguin to $34^{\circ}$ by the time they arrive on the Wadden Sea.

\section{Flight speed}

In the absence of information on differences in flight speed relative to changing flight altitudes and body mass, we assume that throughout the journey our birds fly at a constant airspeed of $57 \mathrm{~km} / \mathrm{h}(15.8 \mathrm{~m} / \mathrm{s})$. This equals the extrapolated value for waders in level flight based on measurements during their take-off from the Banc d'Arguin in spring (pers. obs.; see Piersma \& Bruggemann 1988, Zwarts et al. 1990). An airspeed of $57 \mathrm{~km} / \mathrm{h}$ is perhaps a bit high for some small calidrid and the tringid wader species (pers. obs., Noer 1979) and a bit low for geese (Alerstam 1981). It is certainly a much higher speed than achieved by most passerine migrants (Alerstam 1981), hence our restriction to waterbirds as the focal group.

To enhance the availability of the information in this paper to the uninitiated reader, we have chosen to give flight and wind speeds in ' $\mathrm{km} / \mathrm{h}$ ', rather than in the SIunit ' $\mathrm{m} / \mathrm{s}$ ' $(1 \mathrm{~m} / \mathrm{s}=3.6 \mathrm{~km} / \mathrm{h})$.

\section{Timing of migration}

On the West African Banc d'Arguin, the majority of high arctic breeding waders leave in the last ten days of April and the first ten days of May, but predominantly in early May (Piersma et al. 1990b). We have therefore analysed wind conditions for birds leaving between 30 April and 7 May, and have added published data for the period 22-29 April (from Piersma \& Jukema 1990), a period when Bar-tailed Godwits start their northward journey. High arctic breeding waders and geese leave the Wadden Sea for the northern breeding grounds in late May and early June (e.g. Dick et al. 1987, Ebbinge 1989, Piersma \& Jukema 1990, Blomqvist \& Lindström 1992) and we have chosen 26 May-12 June as the relevant period of starting dates.

\section{Wind-data sources and calculations}

Synoptic wind data for the northern hemisphere are given in the daily European Meteorological Bulletin (Deutscher Wetterdienst in Offenbach, Germany). This bulletin summarizes air pressure (isobars), wind speed and wind direction at ground level, wind speed and wind direction and height at pressure levels of $850 \mathrm{hPa}$ $(=\mathrm{mb})$ (c. $1.5 \mathrm{~km}$ altitude), $700 \mathrm{hPa}($ c. $3 \mathrm{~km})$ and 500 $\mathrm{hPa}(\mathrm{c} .5 .5 \mathrm{~km}$ ) at $00.00 \mathrm{~h}$ Greenwich Mean Time. Wind speed and direction are indicated by flags. In this system, each full 'flag' corresponds to a wind speed of 10 knots (i.e. $18.5 \mathrm{~km} / \mathrm{h}$ or $5.1 \mathrm{~m} / \mathrm{s}$ ).
From these synoptic weather maps we could 'read out' wind speed and wind direction at 13 different locations spread evenly along the predicted routes (Fig. 1). We chose seven different 'read out-locations' along the route from the Banc d'Arguin to the Wadden Sea for this purpose: each representing a partial-trajectory of c. $4200 / 7=600 \mathrm{~km}$. Along the route from the Wadden Sea to Taymyr, six different locations were chosen, c. 4600/ $6=767 \mathrm{~km}$ apart. To read out the wind data for the appropriate date and time, we first constructed travel schemes assuming that the birds started at $18.00 \mathrm{~h}$ at both departure sites (Piersma et al. 1990a) and travelled with a constant groundspeed of $65 \mathrm{~km} / \mathrm{h}$ (or $18.1 \mathrm{~m} / \mathrm{s}$, which is somewhat higher than airspeed in view of the expected tailwind assistance). The first wind measurement read is at midnight $(00.00 \mathrm{~h})$ on the date after the birds had departed. For the subsequent 'read out-locations' we took the measurements at $00.00 \mathrm{~h}$ on the date closest to that on which the birds would have passed the 'read out-location' according to the travel scheme with the constant groundspeed. The reason for choosing so many 'read out- locations' (each partialtrajectory being only half as long as the daily distance covered, $1560 \mathrm{~km}$ ) was to ensure that the weather systems through which the birds migrated were adequately sampled (assuming that the wind variation in space was larger than that in time; see discussion).

For the Banc d'Arguin - Wadden Sea flight, wind patterns were investigated for a 13-year period (1979 to 1991). Due to time limitations, for the subsequent flight from the Wadden Sea to Taymyr wind patterns were analysed only for seven years (1985 - 1991).

The head- or tailwind vectors at different locations and altitudes were calculated as follows (Fig. 1). If $\alpha$ is the angular difference between the track (migratory) direction $(\mathbf{t})$ and the wind direction ( $\mathbf{w}$, the direction from where the wind is blowing) then $\alpha=\mathbf{w} \pm 180^{\circ}$ - $\mathbf{t}$. If $W$ is wind speed, $A$ is the bird's airspeed (i.e. $57 \mathrm{~km} /$ h) and $G$ is the bird's groundspeed, then the "wind effect' $(\delta W)$ is $G-A$. Since birds try to remain on course, the direction of $\underline{G}$ is always the same as the fixed track direction. According to Fig. 1 (inset) and some geometric rules, $\sin \alpha=x / W$ and therefore $x=W \sin \alpha$. Since $x^{2}+$ $z^{2}=A^{2}, z=\sqrt{A^{2}-x^{2}}$ or $z=\sqrt{A^{2}-(W \sin \alpha)^{2}}$. $\operatorname{Cos} \alpha=y / W$ and therefore $y=W \cos \alpha$. As $G=y+z$, it follows that: $G=W \cos \alpha+\sqrt{A^{2}-(W \sin \alpha)^{2}}$.

The wind effect $\delta W$ is $G-A$, therefore: $\delta W=W \cos \alpha+\sqrt{A^{2}-(W \sin \alpha)^{2}}-A$.

In the text we may also call the wind effect the tailwind vector (when $\delta W>0$ ) or headwind vector (when $\delta W<$ $0)$.

The calculated wind vectors were averaged over the appropriate migration periods, and for flights at constant or varying altitudes. Sometimes, hard winds from unfavourable sideways directions made it impossible 
Table 1 . Wind vectors $(\mathrm{km} / \mathrm{h})$ experienced by migrating waterbirds flying at different altitudes, starting off at the Banc d'Arguin to fly to the Wadden Sea along the great circle route (see Fig. 1) in the period 30 April - 7 May. The values are averages calculated over 8 different starting dates, with standard deviations in brackets. The overall averages and standard deviations refer to $13 \cdot 8=104$ different starting dates.

Motvinds- (minusvärden) och medvindsvektorer $i \mathrm{~km} / \mathrm{h}$ för fåglar som flyttar vid olika altituder längs storcirkelrutten mellan Banc d'Arguin (Mauritanien) och Vadehavet (Holland, Tyskland, Danmark) perioden 30 april - 7 maj. Siffrorna visar medelvärden för åtta olika startdatum (standardavvikelsen inom parentes). Medelvärdena för alla år är räknat på $13 \cdot 8=104$ olika startdagar.

\begin{tabular}{|c|c|c|c|c|c|}
\hline \multicolumn{6}{|c|}{ Flight level Flyghöjd } \\
\hline Year & $\begin{array}{l}\text { Ground } \\
\text { level }\end{array}$ & $1.5 \mathrm{~km}$ & $3 \mathrm{~km}$ & $5.5 \mathrm{~km}$ & $\begin{array}{l}\text { Optimal } \\
\text { track }\end{array}$ \\
\hline$\AA r$ & \multicolumn{4}{|l|}{ Marknivå } & $\begin{array}{l}\text { Optimal } \\
\text { rutt }\end{array}$ \\
\hline 1979 & $\begin{array}{r}-12.8 \\
(4.9)\end{array}$ & $\begin{array}{l}-1.6 \\
(6.4)\end{array}$ & $\begin{array}{l}-1.0 \\
(8.8)\end{array}$ & $\begin{array}{c}-3.9 \\
(11.5)\end{array}$ & $\begin{array}{l}5.5 \\
(6.3)\end{array}$ \\
\hline 1980 & $\begin{array}{l}-8.1 \\
(2.8)\end{array}$ & $\begin{array}{c}-5.2 \\
(12.6)\end{array}$ & $\begin{array}{l}-3.0 \\
(8.1)\end{array}$ & $\begin{array}{c}-3.3 \\
(16.0)\end{array}$ & $\begin{array}{c}6.4 \\
(6.3)\end{array}$ \\
\hline 1981 & $\begin{array}{r}-10.4 \\
(3.5)\end{array}$ & $\begin{array}{c}7.8 \\
(17.0)\end{array}$ & $\begin{array}{c}14.2 \\
(19.2)\end{array}$ & $\begin{array}{c}15.0 \\
(26.8)\end{array}$ & $\begin{array}{c}23.6 \\
(19.5)\end{array}$ \\
\hline 1982 & $\begin{array}{l}-9.0 \\
(3.3)\end{array}$ & $\begin{array}{c}3.5 \\
(11.0)\end{array}$ & $\begin{array}{c}19.1 \\
(22.5)\end{array}$ & $\begin{array}{c}19.9 \\
(17.0)\end{array}$ & $\begin{array}{c}24.5 \\
(19.4)\end{array}$ \\
\hline 1983 & $\begin{array}{l}-4.8 \\
(4.3)\end{array}$ & $\begin{array}{l}11.0 \\
(4.4)\end{array}$ & $\begin{array}{l}23.0 \\
(8.3)\end{array}$ & $\begin{array}{c}37.3 \\
(13.4)\end{array}$ & $\begin{array}{l}36.0 \\
(9.5)\end{array}$ \\
\hline 1984 & $\begin{array}{l}-8.5 \\
(6.2)\end{array}$ & $\begin{array}{l}-10.9 \\
(16.0)\end{array}$ & $\begin{array}{c}-1.5 \\
(21.5)\end{array}$ & $\begin{array}{c}-0.3 \\
(13.1)\end{array}$ & $\begin{array}{c}12.6 \\
(11.1)\end{array}$ \\
\hline 1985 & $\begin{array}{r}-11.7 \\
(5.9)\end{array}$ & $\begin{array}{l}-13.8 \\
(15.4)\end{array}$ & $\begin{array}{l}-15.8 \\
(13.5)\end{array}$ & $\begin{array}{l}-11.6 \\
(10.8)\end{array}$ & $\begin{array}{c}3.3 \\
(5.3)\end{array}$ \\
\hline 1986 & $\begin{array}{l}-4.5 \\
(2.0)\end{array}$ & $\begin{array}{l}11.4 \\
(4.7)\end{array}$ & $\begin{array}{c}22.3 \\
(11.1)\end{array}$ & $\begin{array}{l}17.2 \\
(9.1)\end{array}$ & $\begin{array}{l}23.8 \\
(5.7)\end{array}$ \\
\hline 1987 & $\begin{array}{l}-8.1 \\
(5.8)\end{array}$ & $\begin{array}{l}-13.8 \\
(21.7)\end{array}$ & $\begin{array}{c}-9.7 \\
(17.9)\end{array}$ & $\begin{array}{c}5.8 \\
(19.2)\end{array}$ & $\begin{array}{c}20.6 \\
(13.0)\end{array}$ \\
\hline 1988 & $\begin{array}{l}-4.8 \\
(1.9)\end{array}$ & $\begin{array}{c}7.7 \\
(6.5)\end{array}$ & $\begin{array}{l}14.4 \\
(7.8)\end{array}$ & $\begin{array}{l}17.6 \\
(9.8)\end{array}$ & $\begin{array}{l}18.0 \\
(7.7)\end{array}$ \\
\hline 1989 & $\begin{array}{l}-5.8 \\
(2.4)\end{array}$ & $\begin{array}{c}-5.7 \\
(11.9)\end{array}$ & $\begin{array}{c}0.0 \\
(11.1)\end{array}$ & $\begin{array}{c}7.5 \\
(13.2)\end{array}$ & $\begin{array}{l}15.1 \\
(9.8)\end{array}$ \\
\hline 1990 & $\begin{array}{l}-8.3 \\
(3.2)\end{array}$ & $\begin{array}{l}-2.1 \\
(7.8)\end{array}$ & $\begin{array}{c}8.2 \\
(9.6)\end{array}$ & $\begin{array}{c}5.1 \\
(14.4)\end{array}$ & $\begin{array}{c}8.9 \\
(8.9)\end{array}$ \\
\hline 1991 & $\begin{array}{c}-12.8 \\
(3.7)\end{array}$ & $\begin{array}{r}-18.9 \\
(6.9)\end{array}$ & $\begin{array}{l}-26.4 \\
(13.8)\end{array}$ & $\begin{array}{l}-19.3 \\
(11.5)\end{array}$ & $\begin{array}{l}-1.7 \\
(4.8)\end{array}$ \\
\hline $\begin{array}{l}\text { Overall } \\
\text { average }\end{array}$ & $\begin{array}{r}-8.4 \\
(5.0)\end{array}$ & $\begin{array}{c}-2.4 \\
(15.6)\end{array}$ & $\begin{array}{c}3.4 \\
(20.4)\end{array}$ & $\begin{array}{c}6.7 \\
(20.8)\end{array}$ & $\begin{array}{c}15.1 \\
(14.9)\end{array}$ \\
\hline $\begin{array}{l}\text { Medel- } \\
\text { värde för } \\
\text { alla år }\end{array}$ & & & & & \\
\hline
\end{tabular}

for the birds to stay on the assigned fixed tracks (that is, when $W \sin \alpha>A$ ). Assuming that migrating birds would always avoid such situations by changing their flight altitude, these instances were handled as missing cases, and were not used when calculating average wind vectors en route. The birds would also be unable to move if the headwind vectors were stronger than their own flight speed (i.e. when $-W \cos \alpha>A$ ). This procedure does lead to a bias in the averages for differentheight layers in the sense that the circumstances may be less favourable than is apparent from the average values for wind vectors. We have tried to indicate this bias by listing percentages of missing cases for different height layers.

The total wind assistance gained by birds flying along the so-called 'optimal height track' was calculated by averaging the date- and site- specific wind vectorvalues for the most favourable of the four altitudes we analysed. Flight at optimal height tracks assumes that the migrants are somehow able to regularly evaluate the wind conditions at different heights and then choose flight altitudes with the best winds.

\section{Results \\ Differences between years}

The average wind vectors experienced by waders leaving the Banc d'Arguin for the Wadden Sea between 30 April and 7 May were highly variable between years at different altitudes above ground level and along the optimal height track (Table 1). Birds flying along the optimal height track would on average have incurred a tailwind assistance of $15.1 \mathrm{~km} / \mathrm{h}$, a $26 \%$ bonus over their own airspeed of $57 \mathrm{~km} / \mathrm{h}$. Spring 1983 provided extremely favourable winds, the average tailwind of 36 $\mathrm{km} / \mathrm{h}$ adding $63 \%$ to their airspeed (i.e. giving a total average groundspeed of $57+36=93 \mathrm{~km} / \mathrm{h}$ ). In contrast, the spring of 1991 was extremely unfavourable, with opposing (head) winds even along the optimal height track $(-1.7 \mathrm{~km} / \mathrm{h})$. Variations in the favourability of winds between years were synchronous for the different altitudes analysed: annual average winds at different heights and the optimal track (Table 1) correlated positively with each other (all Pearson's r-values > $0.60, \mathrm{n}=13, \mathrm{p}<0.05$ ).

Wind conditions along the route from the Wadden Sea to Taymyr were on average more favourable for the migrating birds than those on the West Africa -Wadden Sea route (Table 2 ). The average tailwind for waders and geese flying along the optimal height track was $21.9 \mathrm{~km} / \mathrm{h}$ as compared to $15.1 \mathrm{~km} / \mathrm{h}$ for Banc d'Arguin - Wadden Sea (or $12.6 \mathrm{~km} / \mathrm{h}$ for the same series of years, 1985-1991, used in the Wadden Sea to Taymyr analysis). With extremes in tailwind vectors along the optimal 
Table 2. Wind vectors (in $\mathrm{km} / \mathrm{h}$ ) experienced by migrating waterbirds flying at different altitudes from the Wadden Sea to the Taymyr Peninsula along the rhumbline route (see Fig. 1) in the period 26 May - 12 June. The values are averages over 18 different starting dates, with standard deviations in brackets. The overall averages and standard deviations refer to $7 \cdot 18=126$ different starting dates.

Motvinds- (minusvärden) och medvindsvektorer $i \mathrm{~km} / \mathrm{h}$ för fåglar som flyttar vid olika altituder med konstant kompassriktning mellan Vadehavet (Holland, Tyskland, Danmark) och Taymyrhalvön (Sibirien) under perioden 26 maj - 12 juni. Siffrorna visar medelvärden för 18 olika startdatum (standardavvikelsen inom parentes). Medelvärdena för alla år är räknat på $7 \bullet 18=126$ olika startdagar.

\begin{tabular}{|c|c|c|c|c|c|}
\hline \multicolumn{6}{|c|}{ Flight level Flyghöjd } \\
\hline Year & $\begin{array}{l}\text { Ground } \\
\text { level }\end{array}$ & $1.5 \mathrm{~km}$ & $3 \mathrm{~km}$ & $5.5 \mathrm{~km}$ & $\begin{array}{l}\text { Optimal } \\
\text { track }\end{array}$ \\
\hline$\AA r$ & \multicolumn{4}{|l|}{ Marknivå } & $\begin{array}{l}\text { Optimal } \\
\text { rutt }\end{array}$ \\
\hline 1985 & $\begin{array}{l}-3.2 \\
(5.2)\end{array}$ & $\begin{array}{c}3.9 \\
(12.4)\end{array}$ & $\begin{array}{c}6.4 \\
(13.2)\end{array}$ & $\begin{array}{c}6.2 \\
(12.0)\end{array}$ & $\begin{array}{l}17.3 \\
(8.3)\end{array}$ \\
\hline 1986 & $\begin{array}{l}-2.8 \\
(4.8)\end{array}$ & $\begin{array}{c}6.5 \\
(11.9)\end{array}$ & $\begin{array}{c}10.0 \\
(13.5)\end{array}$ & $\begin{array}{c}-2.5 \\
(18.1)\end{array}$ & $\begin{array}{c}16.7 \\
(11.2)\end{array}$ \\
\hline 1987 & $\begin{array}{l}-1.4 \\
(6.2)\end{array}$ & $\begin{array}{c}11.4 \\
(15.5)\end{array}$ & $\begin{array}{c}16.3 \\
(19.5)\end{array}$ & $\begin{array}{c}12.8 \\
(20.8)\end{array}$ & $\begin{array}{c}21.6 \\
(17.0)\end{array}$ \\
\hline 1988 & $\begin{array}{l}-4.6 \\
(4.5)\end{array}$ & $\begin{array}{c}8.5 \\
(16.6)\end{array}$ & $\begin{array}{c}9.7 \\
(24.0)\end{array}$ & $\begin{array}{c}3.8 \\
(17.7)\end{array}$ & $\begin{array}{c}16.7 \\
(13.6)\end{array}$ \\
\hline 1989 & $\begin{array}{l}-0.4 \\
(5.0)\end{array}$ & $\begin{array}{c}15.0 \\
(14.0)\end{array}$ & $\begin{array}{c}28.8 \\
(22.5)\end{array}$ & $\begin{array}{c}22.2 \\
(19.8)\end{array}$ & $\begin{array}{c}31.9 \\
(16.8)\end{array}$ \\
\hline 1990 & $\begin{array}{l}-2.4 \\
(6.5)\end{array}$ & $\begin{array}{c}-3.3 \\
(16.2)\end{array}$ & $\begin{array}{c}1.4 \\
(14.9)\end{array}$ & $\begin{array}{c}7.4 \\
(18.2)\end{array}$ & $\begin{array}{c}21.3 \\
(12.5)\end{array}$ \\
\hline 1991 & $\begin{array}{l}-2.2 \\
(4.6) \\
\end{array}$ & $\begin{array}{c}11.5 \\
(10.1) \\
\end{array}$ & $\begin{array}{c}23.6 \\
(10.7) \\
\end{array}$ & $\begin{array}{c}16.7 \\
(12.6)\end{array}$ & $\begin{array}{l}27.6 \\
(8.6)\end{array}$ \\
\hline $\begin{array}{l}\text { Overall } \\
\text { average }\end{array}$ & $\begin{array}{l}-2.5 \\
(5.4)\end{array}$ & $\begin{array}{c}7.6 \\
(15.2)\end{array}$ & $\begin{array}{c}13.7 \\
(19.7)\end{array}$ & $\begin{array}{c}9.5 \\
(18.5)\end{array}$ & $\begin{array}{c}21.9 \\
(14.6)\end{array}$ \\
\hline $\begin{array}{l}\text { Medel } \\
\text { värde för } \\
\text { alla år }\end{array}$ & & & & & \\
\hline
\end{tabular}

height track for the Wadden Sea - Taymyr route of 16.7 $\mathrm{km} / \mathrm{h}(1986,1988)$ and $31.9 \mathrm{~km} / \mathrm{h}(1989)$, the winds along this route showed much smaller year-to-year variability $(\mathrm{SD}=5.9 \mathrm{~km} / \mathrm{h})$ than for the Banc d'Arguin -Wadden Sea route $(\mathrm{SD}=10.6 \mathrm{~km} / \mathrm{h})$ (Tables 2 and 1 , respectively). The smaller year-to-year variability for the second leg of the Africa - Siberia journey still holds over the same seven seasons (1985 to 1991) for which we have analysed wind conditions for both parts of the route $(\mathrm{SD}=9.4 \mathrm{~km} / \mathrm{h}$ for Banc d'Arguin - Wadden Sea leg). Yearly average wind vectors for the different heights and along the optimal height track were also positively correlated for the Wadden Sea - Taymyr trajectory (all r-values $>0.43, \mathrm{n}=7$; six of the 10 calculated r-values were $>0.75$ and significant at the 0.05 level).

\section{Variations with altitude and location along the route}

The winds experienced by migrating birds are highly variable with respect to year, season and site. So far we have taken a coarse-grained approach by comparing years and complete flight routes. Here we examine the data from another viewpoint (though still coarsegrained) by lumping data for all years and then looking at variation between locations along the routes at different heights (Fig. 2). At ground level, winds were usually unfavourable at all locations along the flight route, although least so in the neighbourhood of the Wadden Sea. Winds tended to get more favourable at higher altitudes, but least so as the birds approached their destinations, both the Wadden Sea in early May and the Taymyr Peninsula in early June.

If birds really do fly along the optimal flight tracks, the wind conditions imply that waders departing from the Banc d'Arguin should first ascend to great heights (which they do according to Piersma et al. 1990a), then decrease their flight altitude over Spain until arriving in the Wadden Sea. A month later, birds leaving the Wadden Sea should again ascend to high altitudes, although perhaps not as high as when leaving the Banc d'Arguin, and descend to lower heights upon approaching Taymyr Peninsula. There is also evidence to support part of the latter speculation. Observations made on the weather radar at Helsinki indicate that canutus Knots overfly the Gulf of Finland at altitudes ranging between 1 and $3 \mathrm{~km}$ (Dick et al. 1987). As shown in Fig. 2 (top), by flying at altitudes of $3 \mathrm{~km}$ or higher, migrating birds run a fair risk of being blown off course, especially in the middle parts of both legs of the journey. Near the Banc d'Arguin and the Wadden Sea the high altitude winds are relatively calm and favourable and usually allow waders to remain on course.

\section{Seasonal variation}

Waders and geese tend to depart northwards at rather fixed time periods (Ebbinge 1989, Piersma et al. 1990b), the waders leaving the Banc d'Arguin showing no evidence of responding to local weather conditions (Piersma et al. 1990b). Is there a seasonal time window which on average provides birds with better than usual winds for performing their migrations, in tune with which the birds' annual schedules could evolve? To assess this, we should ideally carry out an analysis for non-migratory and migratory seasons combined (in fact, for the whole year), but we currently lack the resources for such a task. 

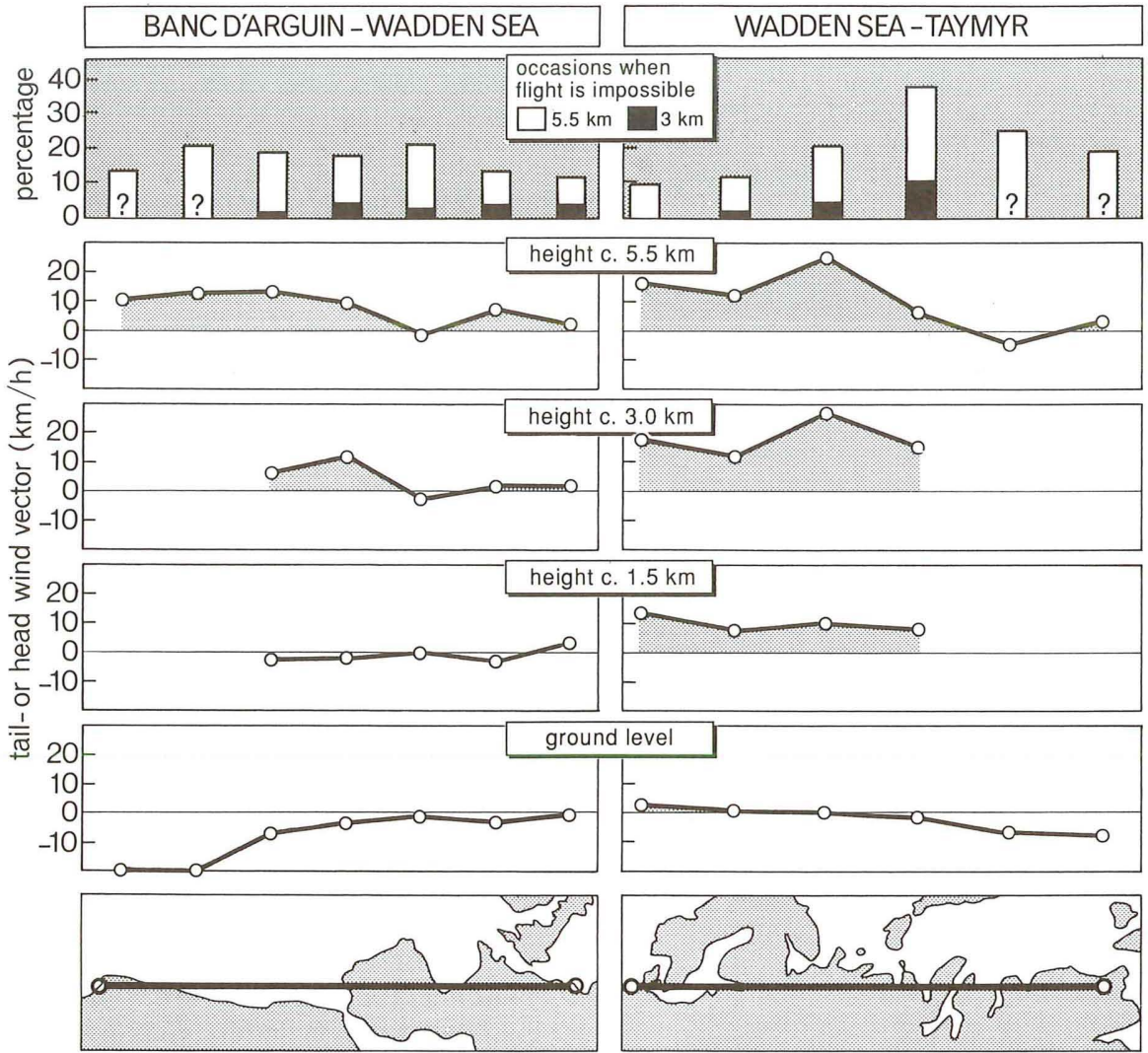

Fig. 2. Geographical and altitudinal variation in the extent of tailwind assistance or headwind opposition along the spring migration route between West Africa and Siberia. The lowest panels show the great circle route between Banc d'Arguin and Wadden Sea, and rhumbline route between Wadden Sea and Taymyr. The two sets of four central panels give the average wind vectors at different locations along the routes (see Fig. 1) at different altitudes (based on the data set outlined in Tables 1 and 2). The two panels at the top give the percentages of occasions on which the winds were too strong to allow waders and geese flying at $57 \mathrm{~km} / \mathrm{h}$ airspeed at heights of $3 \mathrm{~km}$ and 5.5 $\mathrm{km}$ to compensate for wind-drift and stay on the envisaged track. At lower altitudes wind-drift could always be compensated for.

However, we made a preliminary analyses of seasonal changes in wind conditions on each leg during the two migration periods (Fig. 3). For the Banc d'Arguin Wadden Sea leg there is little evidence of systematic seasonal changes (Fig. 3 left), either for the optimal height track or for flights at the different constant altitudes. For the Wadden Sea - Taymyr route there was a tendency for winds to be best in the first and last
Geografisk och höjdmässig variation i genomsnittlig mängd medvind och motvind längs vårflyttningsvägen mellan Mauritanien och Sibirien. De två nedre rutorna visar storcirkelrutten mellan Mauritanien och Vadehavet (t.v.) samt flygrutten med konstant kompassriktning mellan Vadehavet och Sibirien (t.h.). I rutorna ovanför visas genomsnittliga vindvektorer vid olika lokaler, och på olika höjd, längs dessa bådaflygrutter (jämför Tabell 1 och 2). De två översta rutorna visar andelen dagar när vindarna var så kraftiga på 3 och 5,5 km höjd attfåglarna inte skulle kunna kompensera för vinddrift. På lägre höjd skulle fåglarna alltid klarat att kompensera för vinddrift.

portions of the assigned departure period, i.e. from 29 May to 3 June, and from 8 to 10 June. During this part of the journey winds usually are best in the $1.5 \mathrm{~km}$ and $3 \mathrm{~km}$ height layers (Fig. 3). Note also that winds at the highest altitude examined were not the most favourable, a difference from those on the Banc d'Arguin - Wadden Sea trajectory. 


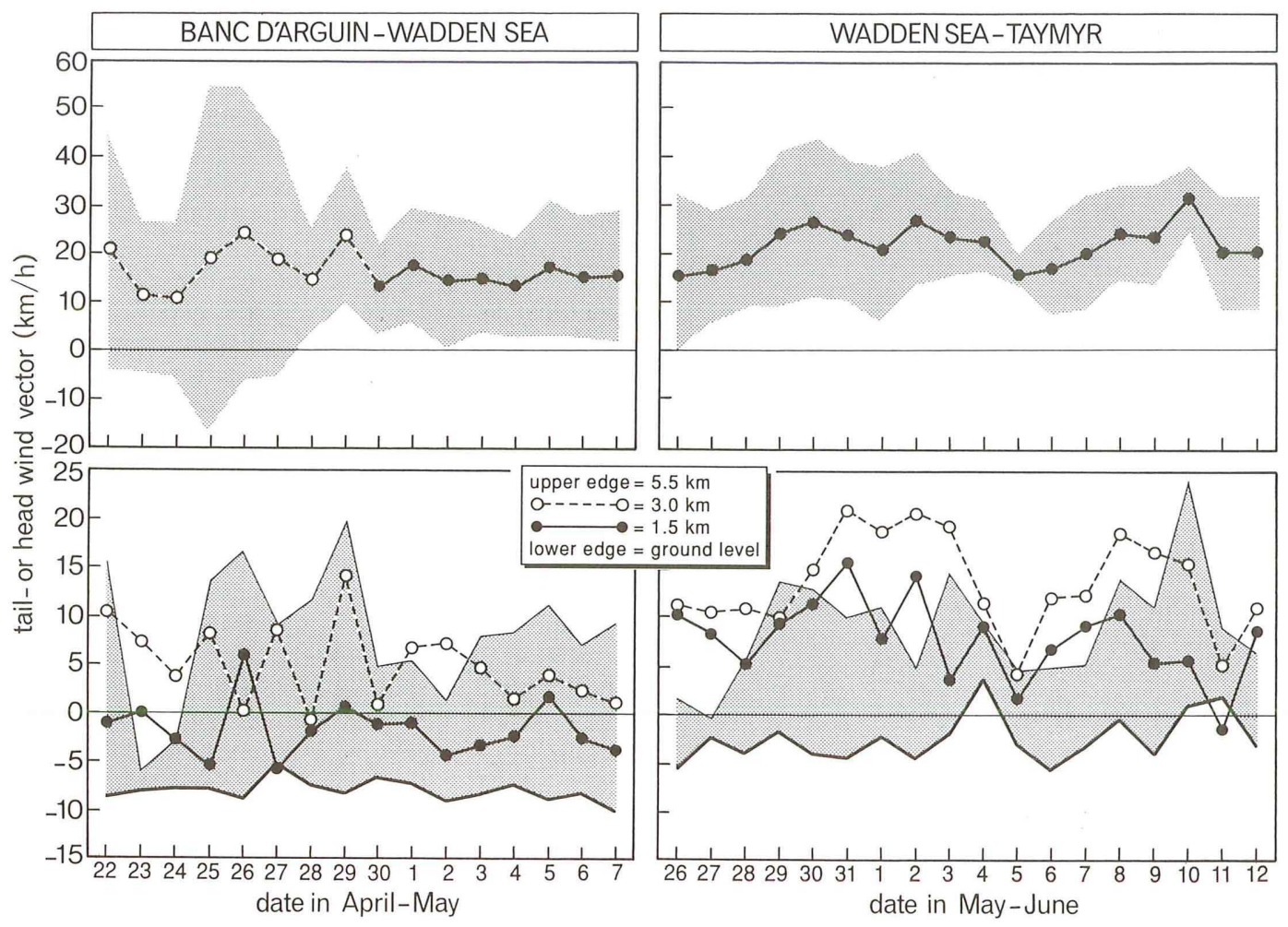

Fig. 3. Seasonal changes in the average winds relative to the birds' movement when migrating from the Banc d'Arguin for the Wadden Sea (left) or from the Wadden Sea for the Taymyr Peninsula (right) at different dates in April-June. The two upper panels give the averages for birds supposedly flying along the optimal height track (the shading enclosing the $95 \%$ confidence intervals), and the lower two panels the date specific averages for birds flying at four different but constant altitudes. The averages and confidence limits for the period 22-29 April (open circles in top left panel) are based on four years of data (1984-1987) analysed by Piersma \& Jukema (1990). For the remaining starting dates, averages are based on data from 1979-1991 (Banc d'Arguin Wadden Sea) or 1985-1991 (Wadden Sea - Taymyr).

Variation under vårsäsongen i genomsnittlig mängd medvind och motvind längs vårflyttningsvägen mellan Mauritanien och Vadehavet (t.v.) och från Vadehavet till Sibirien (t.v.). De två övre rutorna visar genomsnittliga värden för fåglar som flyger en optimal rutt (de anpassar sin flyghöjd efter den fördelaktigaste vinden). Det skuggade området utgördet $95 \%$ konfidensintervallet. De undre rutorna visar värdena för fäglar som håller en och samma flyghöjd (fyra olika höjder är representerade). Värdena för perioden 22-29 april (öppna cirklar i övre vänstra rutan) är baserade på data från 1984-1987 (från Piersma \& Jukema 1990). För övriga startdatum är värden beräknade på data från 1979-1991 (Mauritanien - Vadehavet) respektive 1985-1991 (Vadehavet - Taymyr).

Another way of looking at seasonal variability in wind conditions is to examine the interaction between the average value (absolute favourability) and the stochasticity (unpredictability) of the wind vectors. There was a clear tendency for years with the best wind conditions also to show the largest variability in wind vectors among starting dates (largest standard deviations; Fig. 4). Therefore, bad years are seasonally consistently bad years, but good years are not seasonally consistently good years.

\section{Discussion}

\section{The analytical problem of fixed flight speeds}

For practical reasons we have had to assume that, whatever the tailwinds or headwinds were like during the trips, the birds migrated with a constant groundspeed of $65 \mathrm{~km} / \mathrm{h}$, and the readings on the weather maps were taken accordingly. In cases where birds would experience a severe wind effect, e.g. strong tailwinds, this could lead them to 'overtake' the normal scheme, 


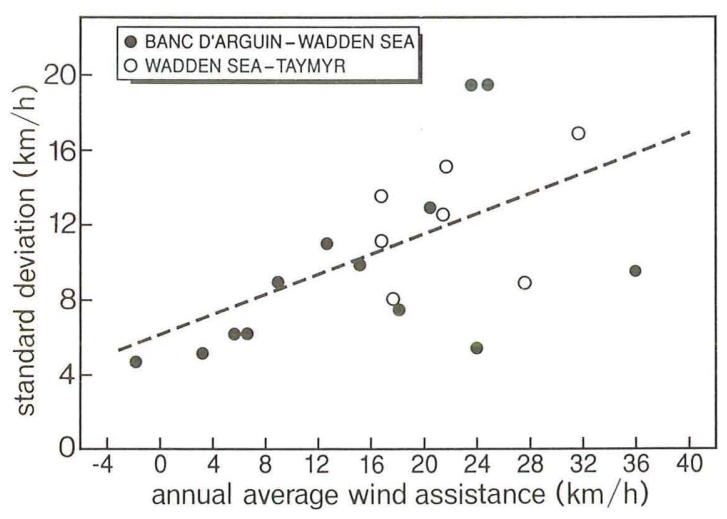

Fig. 4. Variability in the average wind vector experienced by birds flying along the optimal height track from the Banc d'Arguin to the Wadden Sea (closed dots, values from Table 1), and from the Wadden Sea to Taymyr (open circles, values from Table 2). The relationship through all data points (broken line $)$ is given by the regression $\mathrm{Y}=6.1+0.27 \cdot \mathrm{X}\left(\mathrm{r}^{2}=0.32\right.$, $\mathrm{p}<0.05)$, and through the data points for Banc d'ArguinWadden Sea only, by $\mathrm{Y}=5.9+0.26 \cdot \mathrm{X}\left(\mathrm{r}^{2}=0.31, \mathrm{p}<0.05\right)$.

Sambandet mellan årlig genomsnittlig med-(eller mot)vindsvektor och standardavvikelsen samma år förfäglar som flyger den optimala flygrutten mellan Mauritanien och Vadehavet (fyllda cirklar, data från Tabell 1), och från Vadehavet till Taymyr (Öppna cirklar, data från Tabell 2). Sambandet mellan samtliga punkter (streckad linje) beskrivs bäst som $Y=6,1+0,27 \cdot X \quad\left(r^{2}=0,32, \quad p<0,05\right)$. Enbart för sträckan Mauritanien - Vadehavet är sambandet $Y=5,9+0,26 \bullet X$ $\left(r^{2}=0,31, p<0,05\right)$.

and in reality be flying on the next departure day's scheme. This would not matter if wind conditions on successive days were correlated, but it would be a problem when birds fly in rapidly moving weather systems and conditions on successive days would not correlate at all. It is therefore nice to see that the en route wind conditions for successive departure days were strongly correlated (Fig. 5), both for the flight between Banc d'Arguin and Wadden Sea $(r=0.68, n=123$, $\mathrm{p}<0.001 ; 85 \%$ of wind vectors on successive days are within $15 \mathrm{~km} / \mathrm{h}$ of each other) and for the Wadden SeaTaymyr trajectory $(\mathrm{r}=0.60, \mathrm{n}=119, \mathrm{p}<0.001 ; 82 \%)$.

\section{Jet streams?}

Winds tend to get stronger with increasing altitude. Indeed, as we have seen above, waders on the move between West Africa and Europe can get more wind assistance the higher they fly. So what made us stop analysing winds at an altitude of c. $5.5 \mathrm{~km}$ when some bird species, including waders, are known to be able to fly at altitudes up to about $10 \mathrm{~km}$ (Alerstam 1981)? This would get us close to the altitudes of the jet streams (10$12 \mathrm{~km}$ ), the well known predictable large-scale winds which are used by the commercial jet-engined airliners. The reason is that using such high-altitude streams is only profitable within the realm of fast (900-1100 km/ h) and large $(350,000 \mathrm{~kg})$ bodies like Boeing 747 Jumbo-Jets. With a flight speed of only about $60 \mathrm{~km} / \mathrm{h}$, winds of $100-300 \mathrm{~km} / \mathrm{h}$ would easily blow a wader off course, and there would be nothing that it could do about it but descend. Even at altitudes of only $5.5 \mathrm{~km}$, the strong winds would make it impossible to remain on course on 10-30\% of the days examined (Fig. 2). Unless the winds are in exactly the right direction, higher altitude winds and jet streams are not suitable carriers for migrating waterbirds.

\section{Fixed routes, wind-drift and the real world}

An exercise such as this would not have been possible without making two more rather drastic and linked assumptions: 1) that birds fly along fixed flight routes and therefore 2) show complete compensation for winddrift. In reality, the only available data on some of the species examined here have shown that birds leaving the Banc d'Arguin allow themselves to be wind-drifted, at least initially (Piersma et al. 1990a). The average wind- drift incurred along the northwest African coast is, however, to the east. This would be compensated for by the rather westerly orientation of the birds, which would, as a result, predict that the waders would closely follow the great circle route.

Alerstam (1979b) predicted that, to save travel time, migrating birds facing variable winds should allow themselves to be wind-drifted during the first part of a long journey but should increasingly correct for winddrift as they approach their destination. Another series of theoretical arguments, developed by Alerstam (1979a) for a typical long distance flight situation, suggests that migrants should initially allow themselves to be partially drifted by strong winds at high altitudes and subsequently correct for the displacement at low altitude under relatively weaker winds. On the basis of the occurrence of favourable winds we predict a corresponding flight height scenario: that in the course of each leg of the journey from West Africa to Siberia, birds would on average profit from decreasing their flight height since the winds tend to get better at lower altitudes (Fig. 2).

\section{Altitudinal sampling of winds?}

Our birds would only be able to travel along the optimal track if they could continuously choose the flight altitude with the best wind conditions. This implies that birds should be able to judge wind speed and direction while aloft, and also that they should regularly make the relevant comparisons between altitudes, either by trying out the winds themselves (Alerstam 1985) or, possibly, by judging the height and movements of clouds below 
Fig. 5. The level of wind assistance along the optimal height track on day 1 is a fair predictor of the level of wind assistance on day 2, both for the Banc d'Arguin-Wadden Sea trajectory (top) as for the Wadden Sea- Taymyr trajectory (bottom). Data for all available pairs of starting dates were assembled (see Tables 1 and 2 for details).

Vindassistensen längs den optimal flygrutten för en given dag (Day 1) är en god prediktor för vindassistensen påföljande dag (Day 2). Detta gäller både för sträckorna Mauritanien Vadehavet (övre rutan) och Vadehavet - Taymyr (undre rutan). Samtliga möjliga par av dagar har plockats med $i$ analysen.

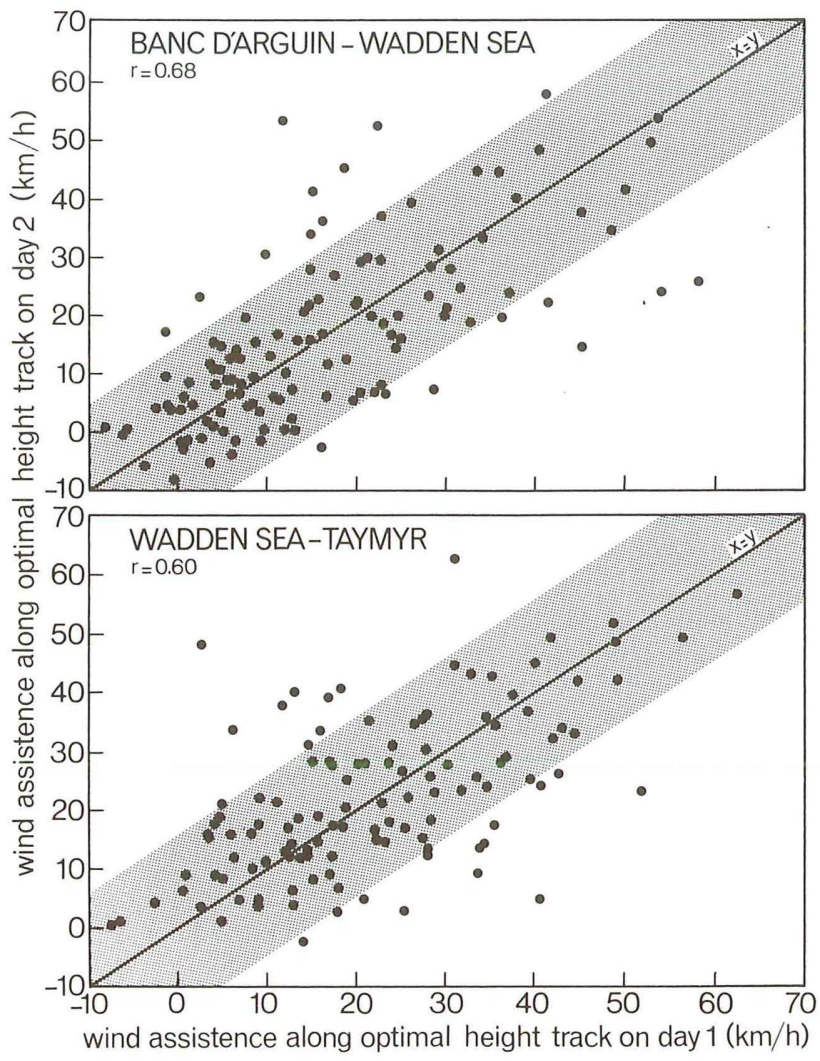

or above them. The correspondence between relatively good wind conditions and flight height, as demonstrated in radar studies by e.g. Bruderer (1971), Steidinger (1972), Richardson $(1976,1979)$ and Alerstam (1985), suggests that many species have the warranted abilities.

\section{Responses to seasonal variation}

If birds were able to succesfully assess the wind conditions en route, or even predict such wind conditions for the nearest future, we would expect them to choose the best (or at least a very good) day for departure. In this case it is not the average of wind conditions over a long period that is interesting, but the wind condition on the best day. One 'good' day out of 14 'bad' would then potentially be enough to make it into a good season. It was shown above that good seasons usually offer variable conditions (Fig. 4) or, in other words, a few very good days among a lot of mediocre departure days. However, waders leaving the Banc d'Arguin in spring did not even chose their departure dates with respect to the local wind conditions at ground level (Piersma et al. 1990b), let alone over the entire trajectory and at greater heights. This suggests that our birds may lack the capability to choose the best day with respect to the wind conditions likely to be encountered during the ensuing 4000-5000 km long flight. The strict seasonal time and travel schedules of many long- distance migrants also argues against taking the outlined analytical problem too seriously. More empirical research is required to address this problem.

\section{West Africa - Siberia: a bipolar wind axis for fast flights?}

Piersma et al. (1991) suggested that Knots of the canutus subspecies migrating between West Africa and Siberia would almost always be able to find favourable winds at certain altitudes, in view of the predominant wind flow patterns along the northern edge of the Eurasian continent (Lamb 1972). The present analysis shows that the winds along both legs of the AfroSiberian journey can be favourable if birds are able to find the best flight altitude (usually at a considerable 
height). The second leg of the journey, when birds fly to the breeding grounds (Wadden Sea - Taymyr), provides more consistently good winds than the Banc d'Arguin - Wadden Sea leg. This is fortunate, since it is the flight before arrival on the breeding grounds that ultimately determines the level of nutrient and energy reserves still available for reproductive purposes (e.g. Piersma 1987, Davidson \& Evans 1988, Ebbinge \& Spaans 1992).

\section{Are yearly wind differences correlated with wader occurrence?}

The hypotheses generated by the work on Bar-tailed Godwits and Knots suggest rather constrained travel budgets and a certain reliance on favourable tailwinds en route. If these hypotheses are correct, we would expect that the considerable yearly variation in the availability of favourable winds, especially for the Banc d'Arguin - Wadden Sea part of the journey, would correlate with the use of stopover sites. In unfavourable springs, waders originating from the Banc d'Arguin would be predicted to arrive either late or lean, or both, in the Wadden Sea. Dick et al. (1987) suggested that the light-weight Knots that stage along the Atlantic coast of France in some years were using this region as an 'emergency' site. Subsequent work in 1985-1988 (D. Bredin pers.comm.; Piersma et al. 1987 and in prep.) has indeed shown that in years of favourable winds en route $(1986,1987)$ much smaller numbers of canutus Knots use the French coast than in years with little potential wind assistance, such as in 1979 and 1985. (We have no French data from 1991.) Further comparative data from the field are eagerly awaited.

\section{Current limitations to the outlined analytical practice}

The sheer amount of desk work required, combined with the limitations of our available time, has severely constrained the number of seasons and dates which we have been able to analyse. Appropriate programmes and the availability of high-powered computer time might eventually allow a computerised analysis of winds as they affect migrants flying with different speeds along different routes in different seasons and years, on the basis of the original meteorological data sets available on the Cray- computer of the European Meteorological Centre in Reading, U.K. (see e.g. de Boer \& Reiff 1987). All this requires considerable investments in terms of time and money. We hope that the present analysis has indicated the scope and promise of such work, and will help to pave the way to more, and perhaps fully computerised, meteornithological explorations!

\section{Acknowledgements}

C. den Hartog and C. Swennen made it possible for SvdS to spend time on this subject in the framework of his biology study at the University of Nijmegen. TP thanks Thomas Alerstam for helping him to overcome the 'meteo- threshold' a couple of years ago. Dick Visser eventually managed to draw the figures. We thank Hugh Boyd, Nick Davidson, Leo Otto, Gudmundur A. Gudmundsson, Jan Beukema, Thomas Alerstam and Åke Lindström for all their important suggestions and criticisms.

\section{References}

Alerstam, T. 1979a. Optimal use of wind by migrating birds: combined drift and overcompensation. J. theor. Biol. 79: 341-353.

Alerstam, T. 1979b. Wind as selective agent in bird migration. Ornis Scand. 10: 76-93.

Alerstam, T. 1981. The course and timing of bird migration. Pp 9-54 in Animal migration (Aidley, D.J. ed). Cambridge University Press, Cambridge.

Alerstam, T. 1985. Strategies of migratory flight, illustrated by Arctic and Common Terns, Sterna paradisaea and Sterna hirundo. Pp 580-603 in Migration: mechanisms and adaptive significance (Rankin, M.A., ed.). Contr. Mar. Sci., Supplement.

Alerstam, T. 1990. Ecological causes and consequences of bird orientation. Experientia 46: 405-415.

Alerstam, T., Hjort, C., Högstedt, G., Jönsson, P.E., Karlsson,J. \& Larsson, B. 1986. Spring migration of birds across the Greenland inlandice. Meddr. Grønland, Biosci. 21: 3-38.

Blomqvist, S. \& Lindström, A. 1992. Routes of spring migrant Siberian and Nearctic Knots Calidris canutus diverge over Sweden. Wader Study Group Bull. 64, Suppl.: 91-94.

Boer, J.H. de \& Reiff, J. 1987. Het voorspellen van trekroutes van sprinkhanenzwermen met hulp van trajectoriënmodellen: een oriëntatie-studie. Technische Rapporten TR-99, KNMI, De Bilt. (In Dutch)

Boyd, H. 1991. Global warming and waterfowl. IWRB News 6: 8-9.

Boyd, H. 1992. Arctic summer conditions and British Knot numbers: an exploratory analysis. Wader Study Group Bull. 64, Suppl.: 144-152.

Bruderer, B. 1971. Radarbeobachtungen über den Frühlingszug im Schweizerischen Mittelland. Orn. Beob. 68: 89-158.

Davidson, N.C. \& Evans, P.R. 1988. Pre-breeding accumulation of fat and muscle protein by arctic breeding shorebirds. Acta XIX Congr. Int. Ornithol. (Ottawa): 342-352.

Dick, W.J.A., Piersma, T. \& Prokosch, P. 1987. Spring migration of the Siberian Knots Calidris canutus canutus: results of a co-operative Wader Study Group project. Ornis Scand. 18: 5-16.

Ebbinge, B.S. 1989. A multifactorial explanation for variation in breeding performance of Brent Geese Branta bernicla. Ibis 131: 196-204.

Ebbinge, B.S. \& Spaans, B. 1992. The importance of bodyreserves accumulated in spring staging areas in the temperate zone for breeding of Dark-bellied Brent Geese Branta $b$. bernicla in the High Arctic. Ardea: in press. 
Elkins, N. 1983. Weather and bird behaviour. Poyser, Calton.

Gauthreaux, S.A., Jr. 1991. The flight behavior of migrating birds in changing wind fields: radar and visual analyses. Amer. Zool. 31: 187-204.

Gudmundsson, G.A., Lindström, Å. \& Alerstam, T. 1991. Optimal fat loads and long distance flights by migrating Knots Calidris canutus, Sanderlings C. alba and Turnstones Arenaria interpres. Ibis 133: 140-152.

Lamb, H.H. 1972. Climate: present, past and future, I: Fundamentals and climate now. Methuen, London.

Metcalfe, J.D., Arnold, G.P. \& Webb, P.W. 1990. The energetics of migration by selective tidal stream transport: an analysis for plaice tracked in the southern North Sea. $J$. mar. biol. Ass. U.K. 70: 149-162

Noer, H. 1979. Speeds of migrating waders Charadriidae. Dansk orn. Foren. Tidsskr. 73: 215-224.

Piersma, T. 1987. Hop, skip or jump? Constraints on migration of arctic waders by feeding, fattening, and flight speed. Limosa 60: 185-191. (In Dutch with English summary)

Piersma, T., Bredin, D. \& Prokosch, P. 1987. Continuing mysteries of the spring migration of Siberian Knots: a progress note. Wader Study Group Bull. 49: 9-10.

Piersma, T. \& Bruggemann, J.H. 1988. Flight trajectories of waders leaving the Banc d'Arguin in spring. Wader Study Group Bull. 54: 8.

Piersma, T. \& Jukema, J. 1990. Budgeting the flight of a longdistance migrant: changes in nutrient reserve levels of Bartailed Godwits at successive spring staging sites. Ardea 78: 315-337.

Piersma, T.,Zwarts, L. \& Bruggemann, J.H. 1990a. Behavioural aspects of the departure of waders before long-distance flights: flocking, vocalizations, flight paths and diurnal timing. Ardea 78: 157-184.

Piersma, T., Klaassen, M., Bruggemann, J.H., Blomert, A.M., Gueye, A., Ntiamoa-Baidu, Y. \& van Brederode, N.E. $1990 \mathrm{~b}$. Seasonal timing of the spring migration of waders from the Banc d'Arguin, Mauritania. Ardea 79: 123-134.

Piersma, T., Drent, R. \& Wiersma, P. 1991. Temperate versus tropical wintering in the world's northernmost breeder, the Knot: metabolic scope and resource levels restrict subspecific options. Acta XX Congr. Int. Ornithol. (Christchurch): 761772.

Richardson, W.J. 1976. Autumn migration over Puerto Rico and the western Atlantic: a radar study. Ibis 118: 309-322.

Richardson, W.J. 1978. Timing and amount of bird migration in relation to weather: a review. Oikos 30: 224-272.

Richardson, W.J. 1979. Southeastward shorebird migration over Nova Scotia and New Brunswick in autumn: a radar study. Can. J. Zool. 57: 107-124.

Richardson, W.J. 1990a. Timing of bird migration in relation to weather: updated review. Pp 78-101 in Bird migration: physiology and ecophysiology (Gwinner, E., ed.). SpringerVerlag, Berlin.

Richardson, W.J. 1990b. Wind orientation of migrating birds: a review. Experientia 46: 416-424.

Steidinger, P. 1972. Der Einfluss des Windes auf die Richtung des nächtlichen Vogelzuges. Orn. Beob. 69: 20-39.

Stoddard,P.K., Marsden, J.E. \& Williams, T.C. 1983. Computer simulation of autumnal bird migration over the western North Atlantic. Anim. Behav. 31: 173-180.
Thomas, D.G. 1970. Wader migration across Australia. Emu 70: $145-154$.

Weihs, D. 1978. Tidal stream transport as an efficient method for migration. Journal du Conseil 38: 92-99.

Zwarts, L., Ens, B.J., Kersten, M. \& Piersma, T. 1990. Moult, mass and flight range of waders ready to take off for longdistance migrations. Ardea 78: 339-364.

\section{Sammanfattning}

Vindarnas mönster och deras förutsägbarhet för vadare och gäss på vårflyttning från Västafrika och Vadehavet till Sibirien.

Vi har analyserat publicerade vinduppgifter från perioden 1979-1991 för att studera vilka möjligheter vadare och gäss har att utnyttja medvindar under flyttningen. Vi undersökte vindförhållandena på olika höjd (från marknivån till 5,5 km höjd) för flygningar från Banc d'Arguin (Mauritanien, Västafrika) till Vadehavet (södra Nordsjön) i slutet på april och i början på maj, samt för sträckan mellan Vadehavet och Taymyrhalvön (Sibirien) i slutet på maj och början av juni (Fig.1). Vi har antagit att fåglarna flyger med en konstant hastighet (mot lufthavet) av $57 \mathrm{~km} / \mathrm{h}$ och att de flyger en storcirkelrutt från Mauritanien till Vadehavet och med konstant kompassriktning från Vadehavet till Sibirien.

Vinduppgifterna utlästes från den dagligt utkommande European Meteorological Bulletin (från Deutscher Wetterdienst i Offenbach, Tyskland) som innehåller synoptiska väderdata från jordklotets norra hemisfär. Från vindkartorna kan man för en gång per dygn (kl. 00.00 GMT) utläsa lufttryck (isobar), vindhastighet och -riktning vid marknivån, samt vid höjder av ungefär $1,5 \mathrm{~km}, 3 \mathrm{~km}$ och $5,5 \mathrm{~km}$. För en hypotetisk fågel som flyger längs de beskrivna rutterna med en konstant hastighet (relativt marken) av $65 \mathrm{~km} / \mathrm{h}$, utlästes vindhastighet och -riktning från vindkartorna vid 13 olika stationer (Fig.1). Med- och motvindsvektorer beräknades utifrån fågelns och vindens vektorer (Fig.1). Eftersom vindförhållandena under två på varandra följande dagar är starkt korrelerade med varandra, längs bägge delarna av flygresan mellan Afrika och Sibirien (Fig.5), går det att använda ett konstant flygschema utan att få något systematiskt fel.

Mellan Västafrika och Vadehavet är det vanligtvis fördelaktigt att flyga högt. Fåglar som klarar att växla flyghöjd och på så sätt kan utnyttja de fördelaktigaste vindarna ("optimal flygrutt") kan åtnjuta en genomsnittlig medvind på $15 \mathrm{~km} / \mathrm{h}$ (medelvärde av årliga medelvärden, Tabell 1). Det var dock stor variation mellan åren med genomsnittliga medvindar längs den optimala flygrutten på $36 \mathrm{~km} / \mathrm{h}$ det bästa året (1991) och motvindar på $2 \mathrm{~km} / \mathrm{h}$ under det sämsta året (1983). Den bästa höjden att flyga på var högre längs Västafrikas kust än över Europa (Fig.2). Det fanns inga förutsägbara 
trender i vindförhållanden under säsongen (Fig.3), men "dåliga" år var dåliga hela säsongen (Fig.4). Mellan Vadehavet och Taymyrhalvön var vindförhållandena normalt fördelaktigare än mellan Västafrika och Vadehavet (genomsnittlig medvindsfaktor längs den optimala flygrutten var över åren $21 \mathrm{~km} / \mathrm{h}$, Tabell 2), med de mest fördelaktiga vindarna på intermediära höjder (1,5-3 km, Fig.2 och 3). Vindförhållandena varierade mindre mellan åren på sträckan Vadehavet och Taymyr, än på första delen av resan.

Genom att flytta på de fördelaktigaste höjderna kan flyttande vadare och gäss få avsevärd assistans av vinden. Risken att bli blåst ur kurs ökar med ökad flyghöjd. Av den anledningen kan inte långsamt flygande fåglar, i motsats till flygplan, utnyttja de jetströmmar som finns på mycket hög höjd. Hela reso- nemanget i denna uppsats bygger på antagandet att fåglarna kan känna av vindarna på olika altituder och anpassa sin flygrutt efter dessa förhållanden. Fåglarnas möjligheter att göra så diskuteras. Ett konkret stöd för att de klarar av detta är att kustsnäppor på flyttning mellan Västafrika och Vadehavet under säsonger med mycket motvind ofta avbryter sin flyttning och utnyttjar en extra rastplats vid den franska Atlantkusten.

Då arbetet med att extrahera vinduppgifter är oerhört tidskrävande har vi varit tvungna att begränsa antalet säsonger i analysen. Vi hoppas dock ha visat potentialen för hur liknande analyser kan lära oss mer om hur fåglarnas flyttning kan påverkas av, och anpassas efter, rådande vindförhållanden. Större datakraft och bättre program kommer i framtiden att möjliggöra analyser på en mer detaljerad nivå. 